\title{
Genetic variability in peppers accessions based on morphological, biochemical and molecular traits
}

\author{
Leonel Vinicius Constantino ${ }^{1}$ (D), Anderson Yusei Suzuki Fukuji ${ }^{1}$ (D), Douglas Mariani Zeffa² (D), \\ Viviane Yumi Baba ${ }^{1}$ (D), Ligia Erpen-Dalla Corte ${ }^{1}$ (D), Renata Mussoi Giacomin ${ }^{1}$ (D), Juliano Tadeu Vilela \\ Resende $^{1}$ (D), Leandro Simões Azeredo Gonçalves ${ }^{1, \star}$ (iD) \\ 1. Universidade Estadual de Londrina - Departamento de Agronomia - Laboratório de Ecofisiologia e Biotecnologia \\ Agrícola - Londrina (Paraná), Brazil. \\ 2. Universidade Estadual de Maringá - Programa de Pós-Graduação em Genética e Melhoramento - Maringá (Paraná), Brazil.
}

\begin{abstract}
The evaluation of genetic diversity among the accessions of a germplasm collection results in information about promising materials suitable for breeding programs. Thus, the goal of this work was to characterize Capsicum baccatum accessions from different Brazilian regions, based on morphological, biochemical and molecular traits, aiming to support chili pepper breeding programs. The fruits were morphologically characterized based on fruit length, diameter, fresh mass and pericarp thickness, and biochemically analyzed for their content in ascorbic and phenolic acids, flavonoid and antioxidant activity by 2,2-diphenyl-1-picrylhydrazyl radical (DPPH•) and ferric reducing antioxidant power (FRAP) assays. All phenotypic traits showed significant differences among the chili pepper accessions, indicating a wide variability. The fruits were also characterized using amplified fragment length polymorphism (AFLP) molecular markers. The combination of six AFLP primers resulted in 1117 bands, 1033 of which were polymorphic. Divergence between accessions was estimated by the Ward's hierarchical agglomerative clustering method, resulting in three and two clusters for fruit phenotypic traits and molecular data, respectively. In Bayesian analysis, molecular data also clustered the accessions in two groups. There was no association between the phenotypic descriptors and AFLP markers, indicating that both characterizations are important to better understand the genetic variability. Furthermore, it was not possible to group the accessions solely based on their origin for neither phenotypic descriptors and AFLP markers. The accessions G1, G5, G6, and $\mathrm{G} 20$ showed interesting characteristics and can be used in breeding programs, aiming the development of Capsicum spp. cultivars with desirable morphological and biochemical traits.
\end{abstract} Key words: Capsicum baccatum, germplasm bank, AFLP, molecular markers, fruit quality.

\author{
Received: \\ Dec. 25, 2019 \\ Accepted: \\ Sep. 8, 2020 \\ Section Editor: \\ Luciana Aparecida Carlini Garcia \\ ${ }^{\star}$ Corresponding author: \\ leandrosag@uel.br
}

\section{INTRODUCTION}

The demand on quality is evident in the current context of fruit and vegetable consumers perspective, which includes beyond crop-specific standards attributes based on visual criteria (size, shape, color and absence of defects) to encompass new requirements related to nutritional and the functional aspects (Kyriacou and Rouphael 2018). Fruits and vegetables with higher antioxidant compounds whose consumption has been associated with health benefits and fruits with high content of sugars and organic acids essentials for flavor intensity. Thus, the goals of horticultural plant breeding programs, so far focused on agronomic performance, have been expanded to meet the new requirements specifically linked to consumer preferences and product differentiation (Kaushik et al. 2015). 
Pepper (Capsicum spp.) is an economically important horticultural crop that has been widely used in worldwide cuisines as both a vegetable (bell peppers) and as spices for condiments purposes (chili peppers) (Zimmer et al. 2012). The Capsicum genus comprises 38 described species, among them some domesticated as C. annuum L., C. chinense Jacq., C. frutescens $\mathrm{L}$., C. pubescens Ruiz et Pav. and C. baccatum L., with wide morphological variation (Nicolaï et al. 2013). Central America is considered the center of origin for Capsicum, and some countries of South America, including Brazil, are considered as important centers of diversity. Capsicum domesticated species are diploids, with $\mathrm{n}=12$ and relatively large genome sizes at $\sim 3.5 \mathrm{~Gb}$ (Kim et al. 2014; Qin et al. 2014).

Characterization and evaluation of accessions conserved in germplasm banks have become of great importance due to the gradual loss of genetic variability and the search for different agronomic traits between the accessions, such as productivity, resistance to biotic and abiotic stresses and nutritional quality of fruits. Chili and bell peppers are recognized as important sources of antioxidant including common compounds present in other plants, such as carotenoids, flavonoids, ascorbic acid (vitamin C), tocopherol (vitamin E) as well as specific component such as capsaicinoids, responsible for the pungency (Bogusz Junior et al. 2018). However, it is also known that there is a wide genetic variability for production of these compounds among domesticated pepper species. A study has shown that C. baccatum exhibit higher levels of phenolic compounds, capsaicinoids, ascorbic acid, as well as greater antioxidant activity (Neitzke et al. 2015) compared to C. annuum and C. frutescens. Thus, characterization and use of the C. baccatum genetic diversity for traits related to fruit quality, including biochemical compounds represents a key point for the progress of the improving health- and flavorrelated compounds in chili peppers (Albrecht et al. 2012).

Capsicum baccatum is one of the most consumed pepper in South America, including Brazil, where the "dedo-de-moça" and "cambuci" morphological types are very appreciated and predominantly produced by farmers (Leite et al. 2016). In view of the potential diversity for C. baccatum, essential to the development of new and improved cultivars, a germplasm bank was created with accessions found in different regions of Brazil, displaying a wide variability of the fruits in sizes, shapes and colors. However, a little or no information is available in the scientific literature regarding other morphological and biochemical traits of these accessions. Also, molecular markers have been widely used in the characterization of germplasm, mainly for providing information on genetic variability of DNA, while avoid influence of environmental conditions or plant development (Albrecht et al. 2012). Among the molecular markers available, amplified fragment length polymorphism (AFLP) has some attractive attributes including large genome coverage, good reproducibility, costs and effectiveness (Wahyuni et al. 2013). The evaluation of genetic diversity among the accessions of a germplasm collection results in information about promising materials suitable for breeding programs. Thus, the aims of this research were: $i$ ) to characterize C. baccatum accessions from different Brazilian regions based on morphological, biochemical and molecular traits, and ii) identify promising genotypes for support pepper breeding programs.

\section{MATERIAL AND METHODS}

\section{Experimental site and plant material}

Twenty-two C. baccatum pepper accessions were sampled from four Brazilian states: Rio de Janeiro, Minas Gerais, Mato Grosso and Mato Grosso do Sul (Fig. 1), representing major sources of variation among landraces that are present in Brazil. The experiments were conducted in State University of Londrina, Paraná, Brazil. The seeds from this collection were sown in 128-cell polystyrene trays containing the substrate Plantmax HT. After germination and growth indoors for 30 days, plants were transplanted into plant beds and grown outdoors in the experimental area during the summer of 2017. The experiment was conducted in a randomized block design with three replicates. Five plants were conducted in each plot, composed of a row of $4 \mathrm{~m}$ and spacing of $0.45 \mathrm{~m}$ among plants and $1.0 \mathrm{~m}$ among plots completely random design with two replications. The plants were grown following practices recommended for chili pepper cultivation, include water supplementation by irrigation, weeding for weeds control and chemical control of pests and chemical control of pests and diseases. 

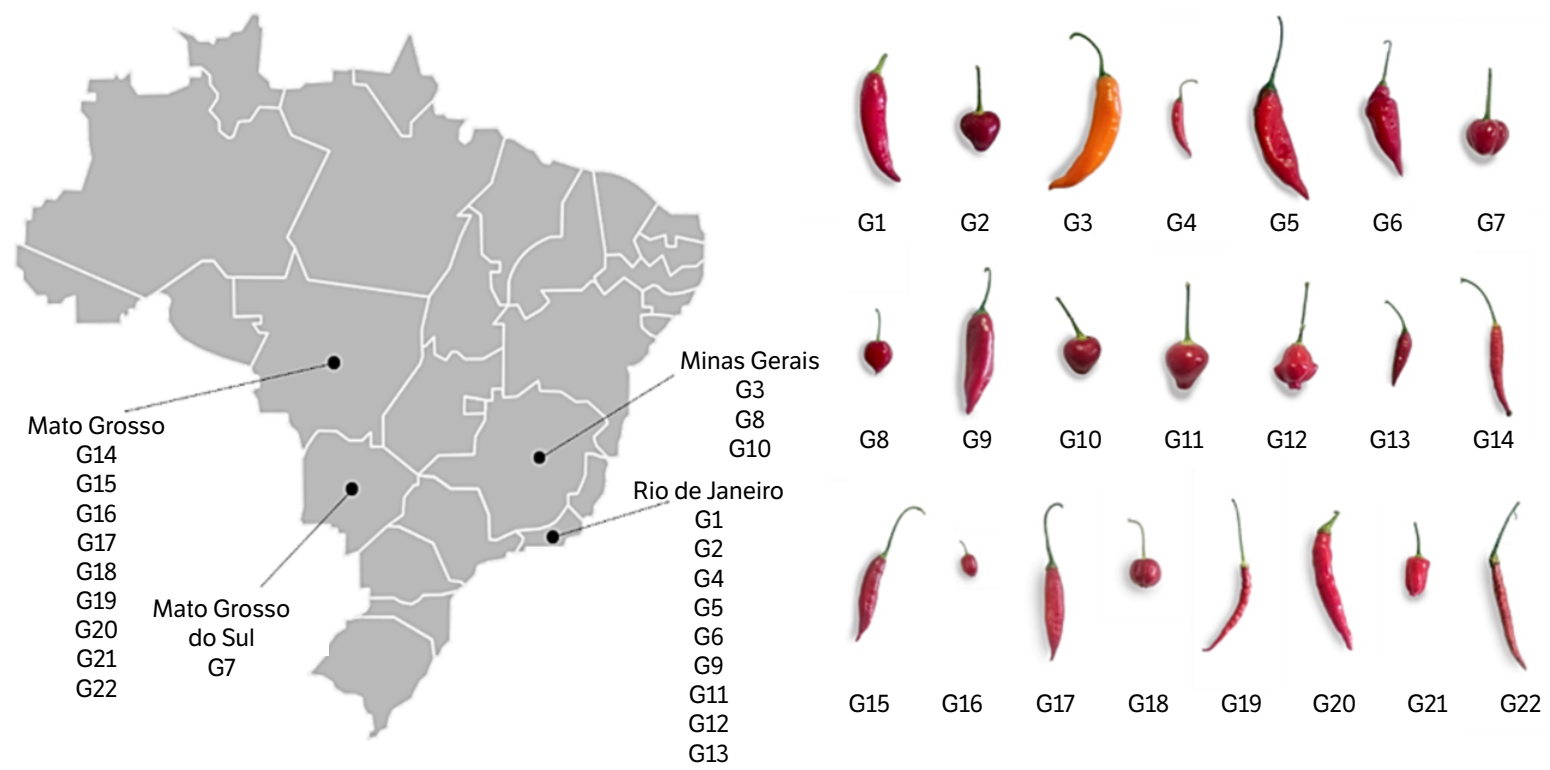

Figure 1. Geographic distribution of 22 C. baccatum accessions.

\section{Fruits morphological characterization}

Ten pepper fruits were characterized based on four quantitative descriptors: fruit length (FL, $\mathrm{cm}$ ), fruit diameter (FD, $\mathrm{mm}$ ), pericarp thickness (PT, $\mathrm{cm}$ ) and fresh mass (FM, g) according to the International Plant Genetic Resources Institute (currently named Biodiversity International) descriptors for Capsicum spp. (IPGRI 1995).

\section{Biochemical compounds content}

\section{Vitamin C content}

Vitamin C content was quantified by the standard AOAC method (AOAC 1984) modified by Benassi and Antunes (1988), using $10.0 \mathrm{~g}$ of fresh fruits and $50 \mathrm{~mL}$ of oxalic acid (Synth) $2 \%(\mathrm{~m} / \mathrm{v})$. Sample extracts were titrated with 2,6-dichlorophenolindophenol and the results expressed as mg ascorbic acid $100 \mathrm{~g}^{-1}$.

\section{Total phenolic content and total flavonoid content}

For quantification of total phenolic content (TPC) and total flavonoid content (TFC), $1.0 \mathrm{~g}$ of fresh samples were mixed with $10 \mathrm{~mL}$ of $80 \%(\mathrm{v} / \mathrm{v})$ methanol and stirring for $30 \mathrm{~min}$ (Orbital New Organic) at room temperature. The mixture (1013 g) was then centrifuged at $2500 \mathrm{rpm}$ (Excelsa 2 Fanem model 205N) for $5 \mathrm{~min}$, and the extract was stored for further analyzes (Vázquez et al. 2008).

For TPC quantitation, $1.0 \mathrm{~mL}$ of extract were added to $1.0 \mathrm{~mL}$ methanol, $1.0 \mathrm{~mL}$ of $0.20 \mathrm{~N}$ Folin-Ciocalteau reagent and $1.0 \mathrm{~mL}$ of $10 \%$ sodium carbonate. The reaction was incubated in the dark at room temperature for $30 \mathrm{~min}$. Subsequently, the absorbance was measured at $765 \mathrm{~nm}$ in a Micronal spectrophotometer (AJX1600, AJ Micronal, São Paulo, Brazil). A calibration curve of gallic acid as standard phenolic compound was plotted (range from 10 to $100 \mathrm{mg} \cdot \mathrm{L}^{-1}$ ). The total phenolic contents from the chili peppers fruits extract were expressed as mg gallic acid equivalents (GAE) per g of fresh weight (Swain and Hillis 1959). 
For TFC quantification, $250 \mu \mathrm{L}$ of extract were added to $75 \mu \mathrm{L}$ of $\mathrm{NaNO}_{2}$ solution (5\%) followed by $1 \mathrm{~mL}$ of $\mathrm{AlCl}_{3}(5.0 \%)$ and $2.0 \mathrm{~mL}$ of methanol after $6 \mathrm{~min}$, and $0.5 \mathrm{~mL}$ of $1.0 \mathrm{~mol} \cdot \mathrm{L}^{-1} \mathrm{NaOH}$ after $5 \mathrm{~min}$. The mixture was incubated in the dark at room temperature for $10 \mathrm{~min}$. Subsequently, the absorbance was measured at $425 \mathrm{~nm}$ in a Micronal spectrophotometer (AJX1600, AJ Micronal, São Paulo, Brazil). A calibration curve of quercetin as standard flavonoid was plotted (range from 1 to $50 \mathrm{mg} \cdot \mathrm{L}^{-1}$ ) and reported as quercetin equivalent (QE) per $\mathrm{g}$ of fresh weight (Gurnani et al. 2016).

\section{Antioxidant activity assays}

Antioxidant activity based on 2,2-diphenyl-1-picrylhydrazyl ( $\left.\mathrm{DPPH}^{\bullet}\right)$ free radical scavenging was performed by adding $50 \mu \mathrm{L}$ of sample extract to $1000 \mu \mathrm{L}$ of acetate buffer $\left(100 \mathrm{mmol} \cdot \mathrm{L}^{-1} ; \mathrm{pH} 5.5\right), 1000 \mu \mathrm{L}$ ethanol and $500 \mu \mathrm{L}$ of ethanolic solution of $\mathrm{DPPH} \bullet\left(250 \mu \mathrm{mol} \cdot \mathrm{L}^{-1}\right)$. The mixture was incubated in the dark at room temperature for $15 \mathrm{~min}$. The DPPH• radical absorbance was measured at $517 \mathrm{~nm}$ in spectrophotometer (Thermo-Genesys) in triplicate. The analytical curve for quantification was prepared using Trolox (6-hydroxy-2,5,7,8-tetramethylchroman-2-carboxylic acid) (0.20 to $1.00 \mathrm{mmol} \cdot \mathrm{L}^{-1}$ ) and the results were expressed in $\mu \mathrm{mol}$ Trolox equivalent antioxidant capacity (TEAC) per $\mathrm{g}$ of sample (Castro-Concha et al. 2014).

The assay based on ferric reducing antioxidant power (FRAP) was performed by adding $50 \mu \mathrm{L}$ of the extract to $1000 \mu \mathrm{L}$ of distilled water and $1000 \mu \mathrm{L}$ of the FRAP reagent. The reaction was incubated at $37^{\circ} \mathrm{C}$ for $5 \mathrm{~min}$. The absorbance was measured at $597 \mathrm{~nm}$ and the analytical curve for quantification was prepared as described above. Results were expressed in $\mu$ mol TEAC per $g$ of sample (Benzie and Strain 1999).

\section{Genotyping by AFLP markers}

The genomic DNA was isolated from young leaves of five plants per accession using an automatic DNA extractor (RetchMM400) following the Doyle and Doyle (1990) protocol with replacement of the cetyltrimethylammonium bromide (CTAB, Sigma-Aldrich, Missouri-USA) by alkyltrimethylammonium bromide (MATAB, Sigma-Aldrich, Missouri-USA) in the extraction buffer. The DNA quality and integrity were checked by electrophoresis and the samples were spectrophotometrically quantified using Nanodrop 2000/2000c (Thermo Fisher Scientific, Waltham, MA, USA).

The AFLP technique was performed as described by Vos et al. (1995) with modifications. Briefly, a mix was prepared

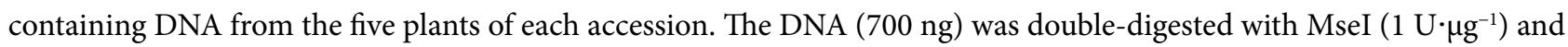
EcoRI $\left(5 \mathrm{U} \cdot \mu \mathrm{g}^{-1}\right)$ restriction enzymes and subsequently ligated to the adapters MseI $\left(5 \mu \mathrm{mol} \cdot \mathrm{L}^{-1}\right)$ and EcoRI $\left(0.5 \mu \mathrm{mol} \cdot \mathrm{L}^{-1}\right)$ in a reaction containing: T4 DNA ligase (2 U); buffer T4 DNA ligase $1 \mathrm{X} ; \mathrm{NaCl}\left(0.05 \mathrm{~mol} \cdot \mathrm{L}^{-1}\right)$; BSA $\left(50 \mu \mathrm{g} \cdot \mu \mathrm{L}^{-1}\right)$; and DTT $\left(0.25 \mathrm{mmol} \cdot \mathrm{L}^{-1}\right)$ up to a final volume of $10 \mu \mathrm{L}$. The program for the digestion-ligation comprised: $37^{\circ} \mathrm{C}$ for $4 \mathrm{~h}, 22^{\circ} \mathrm{C}$ for $1 \mathrm{~h}$ and $70^{\circ} \mathrm{C}$ for $10 \mathrm{~min}$. The digestion-ligation products were separated and visualized by electrophoresis on $1.0 \%$ agarose gel. Once the digestion confirmed, the products were diluted 1:4 with ultrapure water.

For preselective amplification each reaction mixture contained $3.0 \mu \mathrm{L}$ of diluted digestion-ligation product (1:4), $0.58 \mu \mathrm{L}$ of the preselective primers EcoRI+A and MseI+C $\left(4.75 \mu \mathrm{mol} \cdot \mathrm{L}^{-1}\right), 3.5 \mu \mathrm{L}$ of GoTaq Green Master Mix (Promega, Winchester-USA), and DNase-free water (added to a total volume of $10 \mu \mathrm{L}$ ). The cycling conditions were 1 cycle at $72^{\circ} \mathrm{C}$ for $2 \mathrm{~min}, 20$ cycles at $94^{\circ} \mathrm{C}$ for $1 \mathrm{~s}, 56^{\circ} \mathrm{C}$ for $30 \mathrm{~s}, 72^{\circ} \mathrm{C}$ for $2 \mathrm{~min}$ and a final cycle at $60^{\circ} \mathrm{C}$ for $30 \mathrm{~min}$. The PCR products were separated by electrophoresis in agarose gel $(2 \%)$. The amplified products were diluted 1:8 with ultrapure water.

For the selective amplification, 12 combinations of selective EcoRI/MseI primers were initially screened for polymorphism and repeatability. The six most polymorphic combinations were chosen for fluorescent labeling and selective amplification: EcoRI(FAM)/-ACA/MseI-CAC, EcoRI(NED)-AGC/MseI-CTGA, EcoRI(VIC)-ACT/MseI-CAA, EcoRI(PET)-AGC/MseICAG, EcoRI(VIC)-ACT/MseI-CAG, and EcoRI(NED)-ACG/MseI-CTGA.

The reaction mixture contained $2.5 \mu \mathrm{L}$ of diluted amplified products $(1: 8), 0.54 \mu \mathrm{L}$ of each primer MseI $\left(5 \mu \mathrm{mol} \cdot \mathrm{L}^{-1}\right)$ and EcoRI $\left(1 \mu \mathrm{mol} \cdot \mathrm{L}^{-1}\right), 3.5 \mu \mathrm{L}$ of GoTaq Green Master Mix and DNase-free water (added to a total volume of $10 \mu \mathrm{L}$ ). The cycling conditions were 1 cycle at $94^{\circ} \mathrm{C}$ for $2 \mathrm{~min}, 65^{\circ} \mathrm{C}$ for $30 \mathrm{~s}$ and $72^{\circ} \mathrm{C}$ for $2 \mathrm{~min} ; 8$ cycles at $94^{\circ} \mathrm{C}$ for $1 \mathrm{~s}, 64^{\circ} \mathrm{C}$ for $30 \mathrm{~s}$, and $72^{\circ} \mathrm{C}$ for $2 \mathrm{~min} ; 23$ cycles at $94{ }^{\circ} \mathrm{C}$ for $1 \mathrm{~s}, 56^{\circ} \mathrm{C}$ for $30 \mathrm{~s}$ and $72{ }^{\circ} \mathrm{C}$ for $2 \mathrm{~min}$ and 1 final cycle at $60^{\circ} \mathrm{C}$ for $30 \mathrm{~min}$. The fragments 
were resolved by capillary electrophoresis using the automated DNA analyzer model 3500xL (Applied Biosystems, CaliforniaUSA) and the results were combined into a binary matrix by GeneMapper1software v.4.1 (Applied Biosystems).

\section{Data analysis}

The fruit morphology descriptors and biochemical compounds content were subjected to analysis of variance (ANOVA) and the differences were tested by the F-test $(\alpha=0.05)$ with the means grouped by Scott-Knott test $(\alpha=0.05)$. The estimation of the genetic distance of the quantitative data among the accessions was carried out by the standardized means Euclidean distance. Subsequently, Ward's hierarchical group analysis was performed aiming to maximize the homogeneity within clusters so that the sum of square of error is minimum (Ward Junior 1963). The relative importance of the characteristics was calculated according to Singh (1981) method using the Genes software (Cruz 2016), while the other analyses were performed in R software (R Core Team 2018) using the 'agricolae' (Mendiburu and Simon 2015) and 'dendextend' (Galili 2015) packages.

Jaccard (J) similarity coefficient estimates among accessions were obtained based on molecular data and were used to estimate the genetic dissimilarities between the accessions and the simplified representation was obtained by the Ward's hierarchical agglomeration clustering method using the algorithm 'ward.D2' in software R (Murtagh and Legendre 2014). The correlation between the dissimilarities $(1-\mathrm{J})$ based on Jaccard coefficient estimates and Euclidean distance matrices was performed using the Mantel test, with 1000 permutations. The groups formation was established using the criterion proposed by Charrad et al. (2014) and the comparison of the two dendrograms was performed using a tanglegram plot. These analyzes were performed in R software using the 'ade4' (Dray and Dufour 2007), 'dendextend' (Galili 2015), and 'NbClust' (Charrad et al. 2014) packages.

Based on the molecular data, Bayesian method clustering was performed using Structure V 2.3.4 software (Pritchard et al. 2000) according to method described by Evanno et al. (2005) with 100,000 interactions MCMC (Markov Chain Monte Carlo) with burn-in of 10,000 interactions, assuming mixed clusters (admixture) and correlated allele frequencies. Values of $K$ ranging from 1 to 22 were tested, with 10 independent interactions for each value of $K$. The $K$-number determination was performed using Structure Harvester v0.6.92 (Earl and vonHoldt 2012) and the graphs were generated by the online Structure Plot 2 interface (Ramasamy et al. 2014).

\section{RESULTS AND DISCUSSION}

Characterization of the C. baccatum germplasm, including morphological, nutritional, and organoleptic descriptors is an interesting strategy to conserve the genotypes of a species, in the face of constant processes of environmental degradation and seek promising materials for the breeding programs, especially those focused on fruit quality. All the phenotypic traits showed significant differences among the chili pepper accessions (Table 1), indicating the presence of variability.

Scott-Knott test revealed the arrangement of distinct groups for each attribute (Table 2). The fruit length (FL) ranged from 1.66 to $11.10 \mathrm{~cm}$ (average and coefficient of variation, CV, estimates were $5.36 \mathrm{~cm}$ and $15.16 \%$, respectively) and, according to this attribute, the accessions were classified into six groups. G5 accession $(11.10 \mathrm{~cm})$ was the only constituent of the group with greatest length, while G2, G7, G8, G10 G11, G12, G16, G18 and G21 genotypes formed the group with the lowest ones (1.66 to $3.36 \mathrm{~cm}$ ). The mean of fruit diameter (FD) ranged from 0.44 to $2.65 \mathrm{~cm}$. It was possible to classify the accessions into five distinct groups. The accessions G5, G6, G8, G12, G16, G18 and G21 composed the group with the largest diameters (2.30 to $2.65 \mathrm{~cm}$ ) while G19 and G22 formed the group with the smallest ones $(0.56$ and $0.44 \mathrm{~cm})$. The thickness of the pepper pericarp (PT) ranged from 0.08 to $0.24 \mathrm{~cm}$ (average and CV estimates were $0.14 \mathrm{~cm}$ and $16.50 \%$, respectively) and the accessions were arranged in five distinct groups. G11 was the genotype with the highest mean $(0.24 \mathrm{~cm})$ while most of the accessions (G4, G5, G14, G15, G16, G17, G19, G21 and G22) were in the group with the lowest thickness of the chili pepper pericarp ( 0.08 to $0.11 \mathrm{~cm}$ ). The morphological trait that exhibited the most variation was fresh mass (FM) of the fruits, ranging from 7.07 to $125.31 \mathrm{~g}$ (average $48.45 \mathrm{~g}, \mathrm{CV} 13.65 \%$ ) and according to this attribute the accessions were classified into 
Table 1. Analysis of variance and F-test for morphological and biochemical traits of 22 C. baccatum accessions.

\begin{tabular}{|c|c|c|}
\hline \multirow{2}{*}{ Traits } & \multicolumn{2}{|c|}{ Mean square } \\
\hline & Accessions & Error \\
\hline Fruit length $(\mathrm{cm})$ & $37.36^{\star \star}$ & 0.66 \\
\hline Fruit diameter (mm) & $1.57^{\star \star}$ & 0.04 \\
\hline Pericarp thickness (cm) & 0.09 ** & 0.01 \\
\hline Fresh mass ( $g$ ) & $2,904.62$ ** & 43.76 \\
\hline Total phenolic content (mg GAE $\left.\cdot \mathrm{g}^{-1}\right)$ & $11,890.33^{\star \star}$ & $1,582.23$ \\
\hline Total flavonoid content (mg EQ $\cdot \mathrm{g}^{-1}$ ) & $12.67^{\star \star}$ & 0.10 \\
\hline Vitamin C content $\left(\mathrm{mg} 100 \cdot \mathrm{g}^{-1}\right)$ & $7,023.35^{\star *}$ & 166.08 \\
\hline $\operatorname{FRAP}\left(\mathrm{mg}\right.$ TEAC $\left.\cdot \mathrm{g}^{-1}\right)$ & $0.34^{\star \star}$ & 0.01 \\
\hline $\mathrm{DPPH}\left(\mathrm{mg}\right.$ TEAC $\left.\cdot \mathrm{g}^{-1}\right)$ & $0.17^{*}$ & 0.06 \\
\hline
\end{tabular}

** and * $=$ significant at 0.01 and 0.05 of probability by $F$ test, respectively.

Table 2. Means of each morphological and biochemical traits of 22 C. baccatum accessions

\begin{tabular}{|c|c|c|c|c|c|c|c|c|c|}
\hline \multirow{2}{*}{ Accessions } & \multicolumn{9}{|c|}{ Traits $^{1}$} \\
\hline & FL & FD & PT & FM & TPC & TFC & vec & FRAP & DPPH \\
\hline $\mathrm{G} 1$ & $6.48 \mathrm{~d}$ & $1.42 \mathrm{~d}$ & $0.12 \mathrm{~d}$ & $41.93 \mathrm{e}$ & $44.49 a$ & $4.44 \mathrm{e}$ & 297.0 a & $0.98 b$ & $0.81 a$ \\
\hline G2 & $2.60 \mathrm{f}$ & $1.78 \mathrm{c}$ & $0.14 \mathrm{~d}$ & $31.60 \mathrm{f}$ & $24.17 d$ & $1.39 \mathrm{~h}$ & $94.50 \mathrm{c}$ & $0.38 \mathrm{~d}$ & $0.34 \mathrm{~b}$ \\
\hline G3 & $7.78 \mathrm{c}$ & $1.78 \mathrm{c}$ & $0.15 c$ & $92.32 \mathrm{c}$ & $20.21 d$ & $5.11 \mathrm{~d}$ & $148.5 b$ & $0.44 \mathrm{~d}$ & $0.77 a$ \\
\hline G4 & $7.69 \mathrm{c}$ & $1.78 \mathrm{c}$ & $0.10 \mathrm{e}$ & $108.4 b$ & $21.95 \mathrm{~d}$ & $4.59 \mathrm{e}$ & $89.1 \mathrm{c}$ & $0.65 c$ & $0.42 b$ \\
\hline G5 & $11.1 \mathrm{a}$ & $2.41 a$ & $0.10 \mathrm{e}$ & $109.8 b$ & $45.58 \mathrm{a}$ & $1.69 \mathrm{~h}$ & $67.5 \mathrm{~d}$ & $0.55 c$ & $0.67 a$ \\
\hline G6 & $9.55 \mathrm{~b}$ & $2.65 a$ & $0.16 \mathrm{c}$ & $125.3 \mathrm{a}$ & $27.14 \mathrm{c}$ & $3.14 \mathrm{~g}$ & $51.3 d$ & $0.33 \mathrm{e}$ & $0.13 b$ \\
\hline G7 & $1.66 \mathrm{f}$ & $2.08 \mathrm{~b}$ & $0.18 c$ & $30.45 f$ & $25.36 \mathrm{~d}$ & $6.69 c$ & $56.7 \mathrm{~d}$ & $0.38 \mathrm{~d}$ & $0.68 a$ \\
\hline G8 & $2.77 \mathrm{f}$ & $2.40 \mathrm{a}$ & $0.19 \mathrm{~b}$ & $53.58 d$ & $33.07 c$ & $6.82 c$ & $40.5 \mathrm{~d}$ & $0.42 \mathrm{~d}$ & $0.63 a$ \\
\hline G9 & $6.53 \mathrm{~d}$ & $1.88 \mathrm{c}$ & $0.17 c$ & $53.44 \mathrm{~d}$ & $27.21 \mathrm{c}$ & $2.94 \mathrm{~g}$ & $164.7 b$ & $0.44 \mathrm{~d}$ & $1.06 \mathrm{a}$ \\
\hline $\mathrm{G} 10$ & $1.90 \mathrm{f}$ & $1.78 \mathrm{c}$ & $0.12 \mathrm{~d}$ & $20.31 \mathrm{f}$ & $26.62 \mathrm{c}$ & $2.25 \mathrm{~h}$ & $83.7 c$ & $0.39 \mathrm{~d}$ & $0.61 a$ \\
\hline G11 & $2.04 \mathrm{f}$ & $2.00 \mathrm{~b}$ & $0.24 a$ & $18.66 \mathrm{f}$ & $27.58 \mathrm{c}$ & $2.03 \mathrm{~h}$ & $35.1 \mathrm{~d}$ & $0.53 c$ & $0.41 \mathrm{~b}$ \\
\hline G12 & $2.30 \mathrm{f}$ & $2.30 \mathrm{a}$ & $0.11 \mathrm{~d}$ & $25.08 \mathrm{f}$ & $30.47 c$ & $4.26 \mathrm{e}$ & $51.3 \mathrm{~d}$ & $0.42 \mathrm{~d}$ & $0.16 \mathrm{~b}$ \\
\hline $\mathrm{G} 13$ & $7.41 \mathrm{c}$ & $1.56 \mathrm{~d}$ & $0.13 \mathrm{~d}$ & $50.17 d$ & $29.36 \mathrm{c}$ & $2.94 \mathrm{~g}$ & $67.5 \mathrm{~d}$ & $0.50 \mathrm{c}$ & $0.64 a$ \\
\hline G14 & $7.06 \mathrm{c}$ & $1.25 \mathrm{~d}$ & $0.09 \mathrm{e}$ & $25.21 \mathrm{f}$ & $23.80 \mathrm{~d}$ & $5.02 \mathrm{~d}$ & $67.5 \mathrm{~d}$ & $0.30 \mathrm{e}$ & $0.41 b$ \\
\hline G15 & $6.58 \mathrm{~d}$ & $1.51 \mathrm{~d}$ & $0.11 \mathrm{e}$ & $36.10 \mathrm{e}$ & $29.14 \mathrm{c}$ & $8.20 \mathrm{~b}$ & $56.7 \mathrm{~d}$ & $0.36 \mathrm{~d}$ & $0.67 a$ \\
\hline G16 & $2.66 \mathrm{f}$ & $2.37 a$ & $0.10 \mathrm{e}$ & $43.81 \mathrm{e}$ & $29.66 \mathrm{c}$ & $1.89 \mathrm{~h}$ & $62.1 \mathrm{~d}$ & $0.49 c$ & $0.70 a$ \\
\hline G17 & $6.01 \mathrm{~d}$ & $1.72 \mathrm{c}$ & $0.10 \mathrm{e}$ & $48.72 \mathrm{~d}$ & $29.95 c$ & $8.23 \mathrm{~b}$ & $56.7 \mathrm{~d}$ & $0.41 \mathrm{~d}$ & $0.13 b$ \\
\hline G18 & $2.30 \mathrm{f}$ & $2.32 \mathrm{a}$ & $0.21 \mathrm{~b}$ & $41.81 \mathrm{e}$ & $29.58 \mathrm{c}$ & $2.35 \mathrm{~h}$ & $70.2 \mathrm{~d}$ & $0.38 \mathrm{~d}$ & $0.33 \mathrm{~b}$ \\
\hline G19 & $4.98 \mathrm{e}$ & $0.44 \mathrm{e}$ & $0.11 \mathrm{e}$ & $7.07 \mathrm{~g}$ & $30.84 \mathrm{c}$ & $7.36 \mathrm{c}$ & $54.0 \mathrm{~d}$ & $2.27 a$ & $0.64 a$ \\
\hline G20 & $8.22 \mathrm{c}$ & $2.10 \mathrm{~b}$ & $0.17 c$ & $114.6 \mathrm{~b}$ & $37.67 b$ & $3.07 \mathrm{~g}$ & $108.0 \mathrm{c}$ & $0.21 \mathrm{e}$ & $1.05 \mathrm{a}$ \\
\hline $\mathrm{G} 21$ & $3.36 \mathrm{f}$ & $2.33 a$ & $0.11 \mathrm{e}$ & $48.42 \mathrm{~d}$ & $26.10 \mathrm{~d}$ & $9.13 a$ & $54.0 \mathrm{~d}$ & $0.29 \mathrm{e}$ & $1.12 \mathrm{a}$ \\
\hline $\mathrm{G} 22$ & $5.70 \mathrm{e}$ & $0.56 \mathrm{e}$ & $0.08 \mathrm{e}$ & $9.92 \mathrm{~g}$ & $24.02 \mathrm{~d}$ & $3.54 \mathrm{f}$ & $62.1 \mathrm{~d}$ & $0.55 c$ & $0.43 b$ \\
\hline
\end{tabular}

${ }^{1}$ Fruit length (FL, cm), Fruit diameter (FD, mm), Pericarp thickness (PT, cm) Fresh mass (FM, g), Total phenolic content (TPC, mg GAE· $\mathrm{g}^{-1}$ ), Total flavonoid content

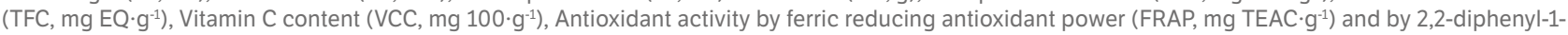

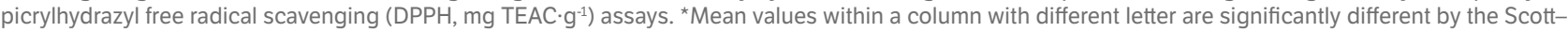
Knott test at 0.05 of probability. 
seven groups. The accession G6 represented the group with the highest mean (125.31 g) that was around fourteen-fold that registered in the G19 and G22 accessions (7.07 and $9.92 \mathrm{~g}$ ), representatives of the group with lowest fresh mass (Table 2).

The total phenolic content (TPC) showed less variation among the genotypes analyzed, ranged from 20.21 to $45.58 \mathrm{mg}$ GAE $100 \cdot \mathrm{g}^{-1}$ (average and CV estimates were $290.45 \mathrm{mg} \mathrm{GAE} 100 \cdot \mathrm{g}^{-1}$ and $13.69 \%$, respectively) and classified as four distinct groups. Highest phenolic content was reported for G1 and G5 genotypes ( 44.49 and $45.58 \mathrm{GAE} \cdot \mathrm{g}^{-1}$ respectively) while G2, G3, G4, G7, G14, G21 and G22 showed the lowest contents (20.21 to $\left.26.10 \mathrm{GAE} \cdot \mathrm{g}^{-1}\right)$. The total flavonoid content (TFC) was very variable among the genotypes forming eight distinct groups. The general mean and CV estimates for this trait were, respectively, $4.62 \mathrm{mg} \mathrm{EQ} \cdot \mathrm{g}^{-1}$, and $6.96 \%$. The group with highest content (G21) showed an amount of $9.13 \mathrm{mg} \mathrm{EQ} \cdot \mathrm{g}^{-1}$ and the group with the lowest (G2, G5, G10, G11, G16 and G18) exhibit amounts ranging from 1.39 to $2.35 \mathrm{mg}$ EQ $\cdot \mathrm{g}^{-1}$. The vitamin $\mathrm{C}$ content (average and CV estimates, respectively, were $87.57 \mathrm{mg}$ of ascorbic acid $100 \cdot \mathrm{g}^{-1}$ and $14.71 \%$ ) discriminated the genotypes in four groups. G1 had the highest vitamin C content (297 $\mathrm{mg}$ of ascorbic acid $\left.100 \cdot \mathrm{g}^{-1}\right)$ that was around fivefold that recorded in the group with lowest content ( 35.1 to $70.2 \mathrm{mg}$ of ascorbic acid $100 \cdot \mathrm{g}^{-1}$ ), composed of most of the genotypes, shown in Table 2.

The antioxidant activity estimated by DPPH • (mean and CV estimates were $0.58 \mu \mathrm{mol} \mathrm{TEAC} \cdot \mathrm{g}^{-1} 43.70 \%$, respectively) was relatively homogeneous among the accessions being possible to differentiate them in only two groups. The group with the highest antioxidant activity was formed by the accessions G1, G3, G5, G7, G8, G9, G10, G13, G15, G16, G19, G20, G21 ranging from 0.61 to $1.12 \mathrm{TEAC} \cdot \mathrm{g}^{-1}$. The lowest antioxidant activity group combined the accessions $\mathrm{G} 2, \mathrm{G} 4, \mathrm{G} 6, \mathrm{G} 11, \mathrm{G} 12$, G14, G17, G18, G22 ranging from 0.13 to $0.43 \mu \mathrm{mol} \mathrm{TEAC} \cdot \mathrm{g}^{-1}$. There was difference in the antioxidant activity of pepper accessions when estimated by the FRAP method (average and CV estimates were, respectively, $0.53 \mu \mathrm{mol} \mathrm{TEAC} \cdot \mathrm{g}^{-1}$ and 9.75\%). In this case, the activity ranged from 0.21 to $2.27 \mu \mathrm{mol} \mathrm{TEAC} \cdot \mathrm{g}^{-1}$ and the genotypes were classified into five distinct groups. The highest antioxidant activity was observed in G19 $\left(2.27 \mu \mathrm{mol} \mathrm{TEAC} \cdot \mathrm{g}^{-1}\right)$ genotype while G6, G14, G20 and G21 constituted the group with lowest antioxidant activity $\left(0.21\right.$ to $\left.0.33 \mu \mathrm{mol} \mathrm{TEAC} \cdot \mathrm{g}^{-1}\right)$ (Table 2$)$.

Several studies have addressed the identification of traits related to quality in Capsicum spp. based mainly on traits such as fruit size, weight, shape, color and seed quality (Baba et al. 2016; Leite et al. 2016; Moreira et al. 2018; Gomes et al. 2020). However, recently the interest for fruits and vegetables with health-promoting compounds, such as vitamin C, phenolics, and flavonoids has been increased. Although these compounds do not present direct nutritional importance, they exhibit antioxidant activity and its consumption has been associated with disease prevention. In Capsicum spp., fewer studies have addressed the characterization based on biochemical compounds (Costa et al. 2010; Rêgo et al. 2011; RodríguezMaturino et al. 2012) and most of them had focused on C. annuum or C. chinense. In this study, the genetic diversity of C. baccatum var. pendulum accessions from different regions of Brazil was investigated.

Wide variation for attributes related to size and weight in the main morphological types cultivated in Brazil was noted: "dedo-de-moça" (elongated fruits) and "cambuci" (bell-shaped fruits), in agreement with description of large diversity in pepper germplasm. The consumer market for fresh peppers has good acceptance for different pepper sizes, although there is a preference for larger fruits in the specific case of "dedo-de-moça" chili pepper (Gomes et al. 2017; Sora et al. 2015). In regard of morphological traits, most of the accessions had a thinner pericarp, which is an important information in the selection of accessions for fresh fruit sale. A thicker pericarp may increase the degree of resistance to pathogens and parasites during postharvest and give a better appearance for consumers than fruits with a thinner pericarp (Lannes et al. 2007). According to grouping analyses, the "cambuci" (bell-shaped fruits) accessions G2, G7, G8, G10, G11, G12, G16, G18 and G21 presented slightly highest levels of pericarp thickness and fruit diameter in relation to "dedo-de-moça".

Considering the biochemical content, flavonoids was the most variable compound among the germplasm and there were accessions with higher content than those reported in the literature (Acunha et al. 2017; Costa et al. 2010). Some accessions also contain a considerable number of phenolic compounds. Bogusz Junior et al. (2018) found in C. frutescens $2.46 \mathrm{mg} \mathrm{GAE} \cdot \mathrm{g}^{-1}$, in C. chinense $2.29 \mathrm{mg} \mathrm{GAE} \cdot \mathrm{g}^{-1}$ and in C. baccatum $2.19 \mathrm{mg} \mathrm{GAE} \cdot \mathrm{g}^{-1}$. Howard et al. (2000) observed in C. annuum $2.56 \mathrm{mg} \mathrm{GAE} \cdot \mathrm{g}^{-1}$, in C. frutescens $5.20 \mathrm{mg} \mathrm{GAE} \cdot \mathrm{g}^{-1}$ and in C. chinense $4.04 \mathrm{mg} \mathrm{GAE} \cdot \mathrm{g}^{-1}$. For vitamin C, genotypes with high levels reaching values as high as $297.0 \mathrm{mg}$ of ascorbic acid $100 \cdot \mathrm{g}^{-1}$ were observed, surpassing the values described

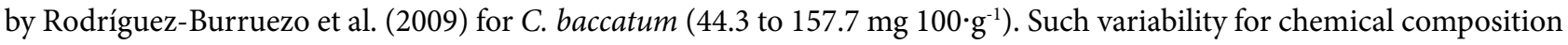
traits will be important to develop chili pepper genotypes with high nutraceutical potential. 
As a consequence of the variability of these compounds, there was also variability in the antioxidant activity estimated by the free radical capture ( $\mathrm{DPPH} \bullet$ ) and $\mathrm{Fe}^{3+}$ reduction (FRAP) assays, widely used in studies involving food including chili peppers (Bogusz Junior et al. 2018; Sora et al. 2015). In general, it has been reported that vitamin $C$ gives the largest contribution to antioxidant activity (Kaur and Kapoor 2001). According to grouping analyses, the accessions G1, G3, G4, G5, G6, G9, G13 and G20 displayed highest values of vitamin C and antioxidant activity by the DPPH• assay.

The relative importance of each of these traits on the phenotypic divergence of the 22 accessions of C. baccatum is shown on Fig. 2. It was possible to observe that the flavonoid content (14.80\%) was the attribute that most contributed to the discrimination of the genotypes, followed by the fruit mass (12.81\%) and fruit length (11.83\%). In contrast, the antioxidant activity was the characteristic that presented less relative importance for the phenotypic divergence (5.57\%).

The divergence between the 22 accessions of C. baccatum was also estimated by the Ward's hierarchical agglomerative clustering method using the Euclidean distance for the morphological and biochemical characteristics. This analysis showed the formation of three distinct groups. Group I was composed of nine accessions (G2, G7, G8, G10, G11, G12, G16, G18 and G21), which presented higher fruit diameter and pericarp thickness, and lowest values for fruit length. Group II was composed of five accessions (G14, G15, G17, G19 and G22), showing the highest values for flavonoids and lowest values of fresh mass, diameter and pericarp thickness. Group III was composed of eight accessions (G1, G3, G4, G5, G6, G9, G13 and G20), presenting highest values of fresh mass and fruit length, vitamin $\mathrm{C}$ and antioxidant activity by the $\mathrm{DPPH} \bullet$ assay (Fig. 3a). The 22 accessions evaluated in this study were sampled from four Brazilian states, described in Fig. 1. However, there was no association between their geographical origin and their morphological and biochemical attributes.

The AFLP markers identified high levels of genetic variability among C. baccatum accession. The combination of the six EcoRI/MseI primers resulted in 1117 bands, 1033 of which were polymorphic (92.48\%). Among these primers, the E-ACT/ M-CAG combination identified the highest number of polymorphisms (286 bands) while the E-ACT/M-CAG combination showed the lowest number of polymorphisms (60 bands). The E-ACT/M-CAA, E-ACG/M-CTGA, E-AGC/M-CTAG and E-AGC/M-CAG combinations generated 176, 191, 194 and 226 polymorphic tags, respectively. The polymorphism was higher than that described by Islam et al. (2016) and Ibiza et al. (2012), who also used AFLP markers to study the genetic diversity of 171 and 260 accessions of Capsicum spp. and found 416 and 1271 amplified bands, of which 254 and 544 were polymorphic, respectively. This difference may be related to the diversity of the accessions as well as the efficiency of the AFLP primer combination to detect polymorphism.

The similarity coefficient estimates used to calculate the genetic dissimilarity $(1-\mathrm{J})$ between the accessions ranged from 0.21 to 0.71 , with a mean dissimilarity of $0.52( \pm 0.08 \mathrm{SD})$. The greatest similarity among genotypes, based on molecular

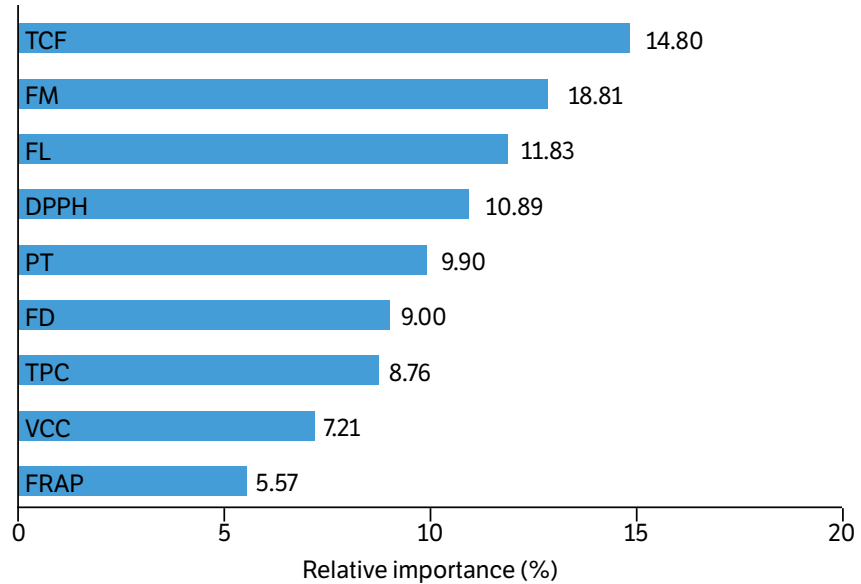

Figure 2. Relative importance of each morphological and biochemical traits on the phenotypic divergence of 22 C. baccatum accessions.

${ }^{1}$ Fruit length (FL, cm), fruit diameter (FD, mm), pericarp thickness (PT, $\mathrm{cm}$ ) fresh mass (FM, g), total phenolic content (TPC, mg GAE g-1), total flavonoid content (TFC, mg EQ g-1), vitamin C content (VCC, mg $100 \mathrm{~g}-1$ ), total antioxidant activity by ferric reducing antioxidant power (FRAP, mg TEAC g-1) and 2,2-diphenyl-1picrylhydrazyl (DPPH•, mg TEAC g-1). 


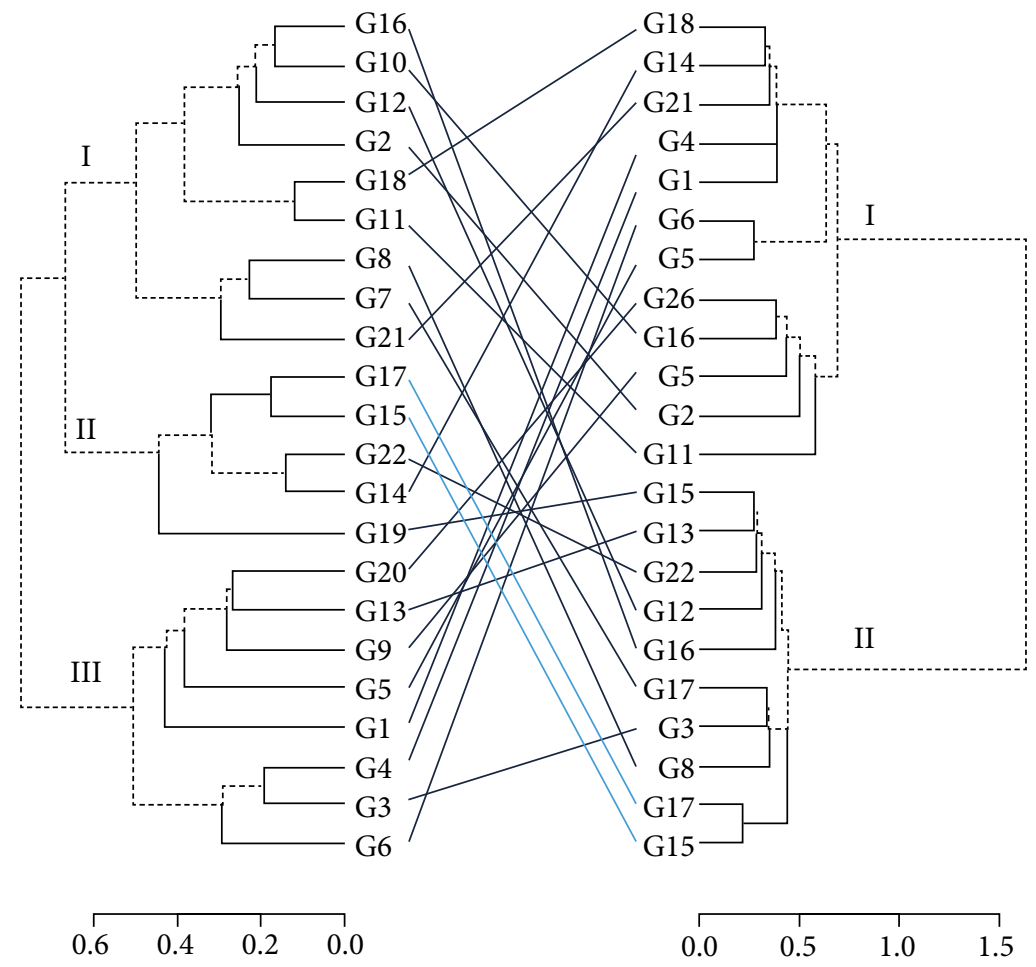

Figure 3. Tanglegram of dendrograms obtained by Ward's method from phenotypic traits (a) based on Euclidean distance and AFLP markers (b) based on Jaccard dissimilarities (1-J) of 22 C. baccatum accessions.

data was observed between G18 and G15, and based on phenotypic measurements was reported between G16 and G6. G15 and G17 were closest to each other in both analyses. The Ward's hierarchical agglomeration clustering method, based on the genetic dissimilarity, classified the accessions into two groups (Fig. 3b). Group I was constituted by 12 accessions (G18, G14, G21, G4, G1, G6, G5, G20, G10, G9, G2, and G11) and Group II by 10 accessions (G19, G13, G22, G12, G16, G7, G3, G8, G17, and G15).

The simulations performed by the $\Delta K$ value method also identified two groups confirming the results of Ward's method (Fig. 4). Although both analyses were conducted based on the molecular data, the structure were carried out with a Bayesian inference that is used to update the probability for a hypothesis as more evidence or information becomes available (Evanno et al. 2005). According to this classification, part of "cambuci" and "dedo-de-moça" accessions are in group I, and the other part in group II. Thus, there was no separation based on peppers type, which has happened based on phenotypic data, since groups II and III comprises the "dedo-de-moça" accessions and group I contains "cambuci" genotypes. On the other hand, group II is more similar to group I than to group III, which was not expected based on the pepper types.

The two groups established according to the AFLP data exhibited a wider variability than the morphological and biochemical traits. These results indicate that both characterizations are important for a better understanding of the genetic variability; precisely because methods and approaches were used to estimate the variations within the germplasm of $C$. baccatum. The species is extremely variable, which confirms the need for this characterization linked to different approaches. Some studies with Capsicum spp. signalized this same observation (Cardoso et al. 2018; Moreira et al. 2018). Similar to phenotypic data, it was not possible to group the accessions according to their origin. This can be attributed to seed exchange between farmers and free fruit transport between the different regions of Brazil, also indicated by Cardoso et al. (2018), besides other authors who have done similar studies (Baba et al. 2016; Canella et al. 2018).

Among the accessions evaluated, G1, G5, G6, and G20 were the accessions that showed the most interesting results in relation to biochemical and morphological traits. The G1 presents medium sized fruits and high levels of phenolic compounds and vitamin $\mathrm{C}$, which resulted in the highest antioxidant activities by both methods used. The accessions G5 and G6 are 


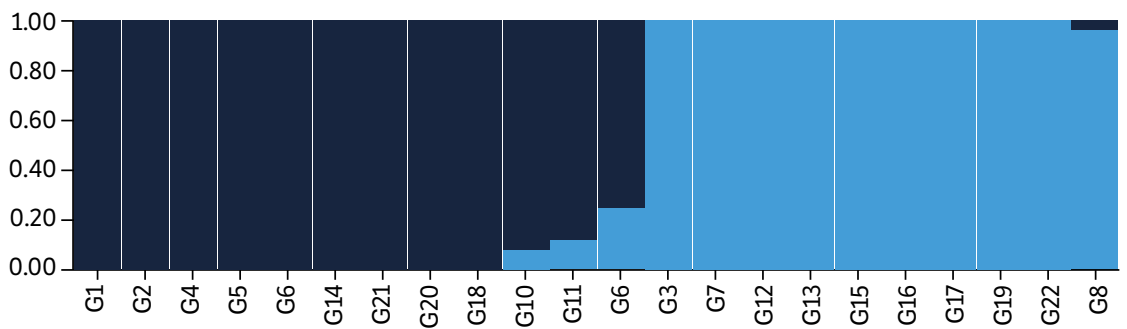

Figure 4. Assignment of $22 \mathrm{C}$. baccatum accessions by the structure bar plots based on six AFLP primer combinations (E-ACA/M-CAC, E-AGC/M-CTAG, E-ACT/M-CAA, E-AGC/M-CAG, E-ACT/M-CAG e E-ACG/M-CTGA). The colors represent different clusters. The $y$-axis displays the estimated percentage membership of each accession in a determined cluster.

among the fruits with larger dimensions (length and diameter) and antioxidant activity. In addition, G5 showed high content of phenolic compounds. The G20 accession exhibited medium-sized fruits and high levels for content of phenolic compounds and antioxidant activity by DPPH $\bullet$ method. Thus, these accessions are interesting to be used in breeding programs aimed the development of Capsicum spp. cultivars with desirable morphological and biochemical traits.

\section{CONCLUSION}

The morphological, biochemical and molecular characterization were useful to detect the genetic variability among twenty-two C. baccatum pepper accessions evidencing its potential use in pepper breeding programs. It was also concluded that the accessions with the most interesting characteristics to be used in the breeding program are G1, G5, G6 and G20.

\section{FUNDING}

This study was financed in part by the Coordenação de Aperfeiçoamento de Pessoal de Nível Superior - Brasil (CAPES) - Finance Code 001

\section{AUTHOR'S CONTRIBUTION}

Conceptualization: Constantino L. V., Zeffa D. M. and Gonçalves L. S. A.; Methodology: Giacomin R. M.; Investigation: Constantino L. V., Baba V. Y. and Fukuji A. Y. S.; Writing - Original Draft: Constantino L. V. and Zeffa D. M.; Writing Review and Editing: Corte L. E.-D. and Baba V. Y.; Resources: Gonçalves L. S. A. and Resende J. T. V.; Supervision: Resende J. T. V. and Gonçalves L. S. A.

\section{REFERENCES}

[AOAC] Association of Official Analytical Chemists. (1984). Official methods of analysis of the Association of Official Analytical Chemists. Arlington: AOAC.

[IPGRI] International Plant Genetic Resources Institute. (1995). Descriptors for Capsicum (Capsicum spp.). Rome: IPGR. [Accessed Dec. 6, 2019]. Available at: https://www.bioversityinternational.org/fileadmin/user_upload/online_library/publications/pdfs/345.pdf

Acunha, T. S., Crizel, R. L., Tavares, I. B., Barbieri, R. L., Pereira, C. M. P., Rombaldi, C. V. and Chaves, F. C. (2017). Bioactive Compound Variability in a Brazilian Capsicum Pepper Collection. Crop Science, 57, 1611-1623. https://doi.org/10.2135/cropsci2016.08.0701 
Albrecht, E., Zhang, D., Saftner, R. A. and Stommel, J. R. (2012). Genetic diversity and population structure of Capsicum baccatum genetic resources. Genetic Resources and Crop Evolution, 59, 517-538. https://doi.org/10.1007/s10722-011-9700-y

Baba, V. Y., Rocha, K. R., Gomes, G. P., Ruas, C. F., Ruas, P. M., Rodrigues, R. and Gonçalves, L. S. A. (2016). Genetic diversity of Capsicum chinense accessions based on fruit morphological characterization and AFLP markers. Genetic Resources and Crop Evolution, 63, 13711381. https://doi.org/10.1007/s10722-015-0325-4

Benassi, M. T. and Antunes, A. J. (1988). A comparison of methaphosphoric and oxalic acids as extractants solutions for the determination of vitamin $\mathrm{C}$ in selected vegetables. Arquivos de Biologia e Tecnologia, 31, 507-513.

Benzie, I. F. F. and Strain, J. J. (1999). Ferric reducing/antioxidant power assay: Direct measure of total antioxidant activity of biological fluids and modified version for simultaneous measurement of total antioxidant power and ascorbic acid concentration Methods Enzymology, 299, 15-27. https://doi.org/10.1016/S0076-6879(99)99005-5

Bogusz Junior, S., Libardi, S. H., Dias, F. F. G., Coutinho, J. P., Bochi, V. C., Rodrigues, D., Melo, A. M. T. and Godoy, H. T. (2018). Brazilian Capsicum peppers: capsaicinoids content and antioxidant activity. Journal of the Science of Food and Agriculture, 98, 217-224. https:// doi.org/10.1002/jsfa.8459

Canella, D. S., Louzada, M. L.C., Claro, R. M., Costa, J. C., Bandoni, D. H., Levy, R. B. and Martins, A. P. B. (2018). Consumption of vegetables and their relation with ultra-processed foods in Brazil. Revista de Saúde Pública, 52, 50. https://doi.org/10.11606/S1518-8787.2018052000111

Cardoso, R., Ruas, C. F., Giacomin, R. M., Ruas, P. M., Ruas, E. A., Barbieri, R. L., Rodrigues, R. and Gonçalves, L. S. A. (2018). Genetic variability in Brazilian Capsicum baccatum germplasm collection assessed by morphological fruit traits and AFLP markers. PLoS ONE, 13, e0196468. https://doi.org/10.1371/journal.pone.0196468

Castro-Concha, L. A., Tuyub-Che, J., Moo-Mukul, A., Vazquez-Flota, F. A. and Miranda-Ham, M. L. (2014). Antioxidant Capacity and Total Phenolic Content in Fruit Tissues from Accessions of Capsicum chinense Jacq. (Habanero Pepper) at Different Stages of Ripening. The Scientific World Journal, 2014, 809073. https://doi.org/10.1155/2014/809073

Charrad, M., Ghazzali, N., Boiteau, V. and Niknafs, A. (2014). NbClust: An R Package for Determining the Relevant Number of Clusters in a Data Set. Journal of Statistical Software, 61, 1-36. https://doi.org/10.18637/jss.v061.i06

Costa, L. M., Moura, N. F., Marangoni, C., Mendes, C. E. and Teixeira, A. O. (2010). Atividade antioxidante de pimentas do gênero Capsicum. Food Science and Technology, 30, 51-59. https://doi.org/10.1590/S0101-20612009005000004

Cruz, C. D. (2016). Genes Software - extended and integrated with the R, Matlab and Selegen. Acta Scientiarum. Agronomy, 38, 547552. https://doi.org/10.4025/actasciagron.v38i3.32629

Doyle, J. J. and Doyle, J. L. (1990). Isolation of plant DNA from fresh tissue. Focus, 12, 13-15.

Dray, S. and Dufour, A.-B. (2007). The ade4 package: Implementing the Duality Diagram for Ecologists. Journal of Statistical Software, 22, 1-20. https://doi.org/10.18637/jss.v022.i04

Earl, D. A. and vonHoldt, B. M. (2012). STRUCTURE HARVESTER: a website and program for visualizing STRUCTURE output and implementing the Evanno method. Conservation Genetics Resources, 4, 359-361. https://doi.org/10.1007/s12686-011-9548-7

Evanno, G., Regnaut, S. and Goudet, J. (2005). Detecting the number of clusters of individuals using the software STRUCTURE: a simulation study. Molecular Ecology, 14, 2611-2620. https://doi.org/10.1111/j.1365-294X.2005.02553.x

Galili, T. (2015). Dendextend: an R package for visualizing, adjusting and comparing trees of hierarchical clustering. Bioinformatics, 31, 3718-3720. https://doi.org/10.1093/bioinformatics/btv428

Gomes, G. P., Damasceno Junior, C. V., Costa, D. S., Queiroz, R. A., Baba, V. Y., Takahashi, L. S. A. and Gonçalves, L. S. A. (2017). Harvest season and seed physiological potential of 'dedo-de-moça BRS Mari’ hot peppers. Semina: Ciências Agrárias, 38, 3897-3906. https:// doi.org/10.5433/1679-0359.2017v38n6p3897 
Gomes, G. P., Zeffa, D. M., Freiria, G. H., Furlan, F. F., Queiroz, R. A., Takahashi, L. S. A. and Gonçalves, L. S. A. (2020). Diallel analysis of "dedo-de-moça" pepper seeds in relation to physiological potential. Horticultura Brasileira, 38, 301-305. https://doi.org/10.1590/ s0102-053620200310

Gurnani, N., Gupta, M., Mehta, D. and Mehta, B. K. (2016). Chemical composition, total phenolic and flavonoid contents and in vitro antimicrobial and antioxidant activities of crude extracts from red chilli seeds (Capsicum frutescens L.). Journal of Taibah University for Science, 10, 462-470. https://doi.org/10.1016/j.jtusci.2015.06.011

Howard, R. L., Talcott, S. T., Brenes, C. H. and Villalon, B. (2000). Changes in Phytochemical and Antioxidant Activity of Selected Pepper Cultivars (Capsicum species) as Influenced by Maturity. Journal of Agriculture and Food Chemistry, 48, 1713-1720. https://doi.org/10.1021/ jf990916t

Ibiza, V. P., Blanca, J., Cañizares, J. and Nuez, F. (2012). Taxonomy and genetic diversity of domesticated Capsicum species in the Andean region. Genetic Resources and Crop Evolution, 59, 1077-1088. https://doi.org/10.1007/s10722-011-9744-z

Islam, M. A., Sinha, P., Sharma, S. S., Negi, M. S., Neog, B. and Tripathi, S. B. (2016). Analysis of genetic diversity and population structure in Capsicum landraces from North Eastern India using TE-AFLP markers. Plant Molecular Biology Reporter, 34, 869-875. https://doi. org/10.1007/s11105-015-0968-5

Kaur, C. and Kapoor, H. C. (2001). Antioxidants in fruits and vegetables - The millennium's health. International Journal of Food Science and Technology, 36, 703-725. https://doi.org/10.1111/j.1365-2621.2001.00513.x

Kaushik, P., Andújar, I., Vilanova, S., Plazas, M., Gramazio, P., Herraiz, F. J., Brar, N. S. and Prohens, J. (2015). Breeding vegetables with increased content in bioactive phenolic acids. Molecules, 20, 18464-18481. https://doi.org/10.3390/molecules201018464

Kim, S., Park, M., Yeom, S.-I., Kim, Y. M., Lee, J. M., Lee, H.-A., Seo, E., Choi, J., Cheong, K., Kim, K.-T., Yung, K., Lee, G.-W., Oh, S.-K., Bae, C., Kim, S.-B., Lee, H.-Y., Kim, S.-Y., Kim, M.-S., Kang, B.-C., Jo, Y. D., Yang, H.-B., Jeong, H.-J., Kang, W.-H., Kwon, J.-K., Shin, C., Lim, J. Y., Park, J. H., Huh, J. H., Kim, J.-S., Kim, B.-D., Cohen, O., Paran, I., Suh, M. C., Lee, S. B., Kim, Y.-K., Shin, Y., Noh, S.-J., Park, J., Seo, Y. S., Kwon, S.-Y., Kim, H. A., Park, J. M., Kim, H.-J., Choi, S.-B., Bosland, P. W., Reeves, G., Jo, S.-H., Lee, B.-W., Cho, H.-T., Choi, H.-S., Lee, M.-S., Yu, Y., Choi, Y. D., Park, B.-S., van Deynze, A., Ashrafi, H., Hill, T., Kim, W. T., Pai, H.-S., Ahn, H. K., Yeam, I., Giovannoni, J. J., Rose, J. K. C., Sørensen, I., Lee, S.-J., Kim, R. W., Choi, I.-Y., Choi, B.-S., Lim, J.-S., Lee, Y.-H. and Choi, D. (2014). Genome sequence of the hot pepper provides insights into the evolution of pungency in Capsicum species. Nature Genetics, 46, 270-278. https://doi.org/10.1038/ng.2877

Kyriacou, M. C. and Rouphael, Y. (2018). Towards a new definition of quality for fresh fruits and vegetables. Scientia Horticulturae, 234, 463-469. https://doi.org/10.1016/j.scienta.2017.09.046

Lannes, S. D., Finger, F. L., Schuelter, A. R. and Casali, V. W. D. (2007). Growth and quality of Brazilian accessions of Capsicum chinense fruits. Scientia Horticulturae, 112, 266-270. https://doi.org/10.1016/j.scienta.2006.12.029

Leite, P. S. S., Rodrigues, R., Silva, R. N. O., Pimenta, S., Medeiros, A. M., Bento, C. S. and Gonçalves, L. S. A. (2016). Molecular and agronomic analysis of intraspecific variability in Capsicum baccatum var. pendulum accessions. Genetics and Molecular Research, 15 , 15048482. https://doi.org/10.4238/gmr.15048482

Mendiburu, F. and Simon, R. (2015). Agricolae - Ten years of an open source statistical tool for experiments in breeding, agriculture and biology. PeerJ PrePrints, 3, e1404v1. https://doi.org/10.7287/peerj.preprints.1404v1

Moreira, A. F. P., Ruas, P. M., Ruas, C. F., Baba, V. Y., Giordani, W., Arruda, I. M., Rodrigues, R. and Gonçalves, L. S. A. (2018). Genetic diversity, population structure and genetic parameters of fruit traits in Capsicum chinense. Scientia Horticulturae, 236, 1-9. https://doi. org/10.1016/j.scienta.2018.03.012

Murtagh, F. and Legendre, P. (2014). Ward's Hierarchical Agglomerative Clustering Method: Which Algorithms Implement Ward's Criterion? Journal of Classification, 31, 274-295. https://doi.org/10.1007/s00357-014-9161-z 
Neitzke, R. S., Vasconcelos, C. S., Barbieri, R. L., Vizzotto, M., Fetter, M. R. and Corbelini, D. D. (2015). Variabilidade genética para compostos antioxidantes em variedades crioulas de pimentas (Capsicum baccatum). Horticultura Brasileira, 33, 415-421. https://doi. org/10.1590/S0102-053620150000400002

Nicolaï, M., Cantet, M., Lefebvre, V., Sage-Palloix, A.-M. and Palloix, A. (2013). Genotyping a large collection of pepper (Capsicum spp.) with SSR loci brings new evidence for the wild origin of cultivated $C$. annuum and the structuring of genetic diversity by human selection of cultivar types. Genetic Resources and Crop Evolution, 60, 2375-2390. https://doi.org/10.1007/s10722-013-0006-0

Pritchard, J. K., Stephens, M. and Donnelly, P. (2000). Inference of population structure using multilocus genotype data. Genetics, 155, 945-959.

Qin, C., Yu, C., Shen, Y., Fang, X., Chen, L., Min, J., Cheng, J., Zhao, S., Xu, M., Luo, Y., Yang, Y., Wu, Z., Mao, L., Wu, H., Ling-Hu, C., Zhou, H., Lin, H., González-Morales, S., Trejo-Saavedra, D. L., Tian, H., Tang, X., Zhao, M., Huang, H., Zhou, A., Yao, X., Cui, J., Li, W., Chen, Z., Feng, Y., Niu, Y., Bi, S., Yang, X., Li, W., Cai, H., Luo, X., Montes-Hernández, S., Leyva-González, M. A., Xiong, Z., He, X., Bai, L., Tan, S., Tang, X., Liu, D., Liu, J., Zhang, S., Chen, M., Zhang, L., Zhang, L., Zhang, Y., Liao, W., Zhang, Y., Wang, M., Lv, X., Wen, B., Liu, H., Luan, H., Zhang, Y., Yang, S., Wang, X., Xu, J., Li, X., Li, S., Wang, J., Palloix, A., Bosland, P. W., Li, Y., Krogh, A., Rivera-Bustamante, R. F., HerreraEstrella, L., Yin, Y., Yu, J., Hu, K. and Zhang, Z. (2014). Whole-genome sequencing of cultivated and wild peppers provides insights into Capsicum domestication and specialization. Proceedings of the National Academy of Sciences, 111, 5135-5140. https://doi.org/10.1073/ pnas.1400975111

R Core Team. (2018). R: A language and environment for statistical computing. Vienna: R Foundation for Statistical Computing. [Accessed Nov. 18, 2019]. Available at: http://www.R-project.org/

Ramasamy, R. K., Ramasamy, S., Bindroo, B. B. and Naik, V. G. (2014). STRUCTURE PLOT: a program for drawing elegant STRUCTURE bar plots in user friendly interface. SpringerPlus, 3, 431. https://doi.org/10.1186/2193-1801-3-431

Rêgo, E. R., Rêgo, M. M., Matos, I. W. F. and Barbosa, L. A. (2011). Morphological and chemical characterization of fruits of Capsicum spp. accessions. Horticultura Brasileira, 29, 364-371. https://doi.org/10.1590/S0102-05362011000300018

Rodríguez-Burruezo, A., Prohens, J., Raigón, M. D. and Nuez, F. (2009). Variation for bioactive compounds in ají (Capsicum baccatum L.) and rocoto (C. pubescens R. \& P.) and implications for breeding. Euphytica, 170, 169-181. https://doi.org/10.1007/s10681-009-9916-5

Rodríguez-Maturino, A., Valenzuela-Solorio, A., Troncoso-Rojas, R., González-Mendoza, D., Grimaldo-Juarez, O., Aviles-Marin, M. and Cervantes-Diaz, L. (2012). Antioxidant activity and bioactive compounds of Chiltepin (Capsicum annuum var. glabriusculum) and Habanero (Capsicum chinense): A comparative study. Journal of Medicinal Plant Research, 6, 1758-1763.

Singh, D. (1981). The Relative Importance of Characters Affecting Genetic Divergence. Indian Journal of Genetics and Plant Breeding, 41, 237-245.

Sora, G. T. S., Haminiuk, C. W. I., Silva, M. V., Zielinski, A. A. F., Gonçalves, G. A., Bracht, A. and Peralta, R. M. (2015). A comparative study of the capsaicinoid and phenolic contents and in vitro antioxidant activities of the peppers of the genus Capsicum: an application of chemometrics. Journal of Food Science and Technology, 52, 8086-8094. https://doi.org/10.1007/s13197-015-1935-8

Swain, T. and Hillis, W. E. (1959). The Phenolic Constituents of Prunus domestica. I. - The Quantitative Analysis of Phenolic Constituents. Journal of the Science of Food and Agriculture, 10, 63-68. https://doi.org/10.1002/jsfa.2740100110

Vázquez, G., Fontenla, E., Santos, J., Freire, M. S., González-Álvarez, J. and Antorrena, G. (2008). Antioxidant activity and phenolic content of chestnut (Castanea sativa) shell and eucalyptus (Eucalyptus globulus) bark extracts. Industrial Crops and Products, 28, $279-285$. https://doi.org/10.1016/j.indcrop.2008.03.003

Vos, P., Hogers, R., Bleeker, M., Reijans, M., van de Lee, T., Hornes, M., Frijters, A., Pot, J., Peleman, J., Kuiper, M. and Zabeau, M. (1995). AFLP: A new technique for DNA fingerprinting. Nucleic Acids Research, 23, 4407-4414. https://doi.org/10.1093/nar/23.21.4407 
Wahyuni, Y., Ballester, A.-R., Tikunov, Y., Vos, R. C. H., Pelgrom, K. T. B., Maharijaya, A., Sudarmonowati, E., Bino, R. J. and Bovy, A. G. (2013). Metabolomics and molecular marker analysis to explore pepper (Capsicum sp.) biodiversity. Metabolomics, 9, 130-144. https:// doi.org/10.1007/s11306-012-0432-6

Ward Junior, J. H. (1963). Hierarchical grouping to optimize an objective function. Journal of the American Statistical Association, 58, 236-244. https://doi.org/10.1080/01621459.1963.10500845

Zimmer, A. R., Leonardi, B., Miron, D., Schapoval, E., Oliveira, J. R. and Gosmann, G. (2012). Antioxidant and anti-inflammatory properties of Capsicum baccatum: From traditional use to scientific approach. Journal of Ethnopharmacology, 139, 228-233. https://doi.org/10.1016/j. jep.2011.11.005

In the article Genetic variability in peppers accessions based on morphological, biochemical and molecular traits with DOI: https://doi.org/10.1590/1678-4499.20190525, published in Bragantia vol.79 no.4 Campinas Oct./Dec. 2020:

In the footline where is read Bragantia, Campinas, v. 79, n. 4, p.433-446, 2020 should be read Bragantia, Campinas, v. 79, n. 4, p.558-571, 2020. 